\title{
Disturbance and growth of juvenile corals (Agaricia humilis and Agaricia agaricites, Scleractinia) in natural habitats on the reef of Curaçao
}

\author{
Godfried W. N. M. Van Moorsel* \\ Caribbean Marine Biological Institute (Carmabi), P.O. Box 2090, Curaçao, Netherlands Antilles
}

\begin{abstract}
Juvenile coral colonies (diameter $<50 \mathrm{~mm}$ ) of Agaricia humilis and A. agaricites (Scleractinia) were studied through time in their natural habitat between 5 and $23 \mathrm{~m}$ depth on the fringing reef of Curaçao (Netherlands Antilles, Caribbean). At 6 censuses (in 1 yr), data were collected on status, morphology and size of juveniles to investigate the following aspects of life histories: frequency of disturbance and mortality, nature of disturbing factors, frequency of fission and fusion processes, and growth during the 5 intervals, as well as annual growth. Absolute linear growth was not dependent on colony size. Maximum linear growth (diameter increase, $80 \mu \mathrm{m} \mathrm{d} \mathrm{d}^{-1}$, was potentially equal in both Agaricia species and independent of depth. However, different disturbance levels, related to depth, resulted in a significant difference in actual annual growth in relation to depth zones. A difference in species-specific coral morphology caused a different level of disturbance in the 2 species. In addition there was a negative relation between coral size and mortality in $A$. humilis juveniles. Dynamic aspects of the life histories of $A$. humilis and $A$. agaricites integrate well with depth-related differences in relative abundance and with differences in reproductive characteristics of the species.
\end{abstract}

\section{INTRODUCTION}

Early life histories of marine invertebrates constitute an important contribution to the development of community structure. On coral reefs this is especially true in the dominating inhabitants, the stony corals (Scleractinia). Species-specific susceptibility to disturbances may be related to morphological characteristics, and recovery after disturbance to growth rate. The importance of different reactions of juveniles in the development of coral population structure has been stressed by Bak \& Engel (1979), Bak \& Luckhurst (1980), Pearson (1981) and Rylaarsdam (1983). In view of this, it is remarkable how few data on growth and disturbance of juvenile corals (primary polyp or colony diameter $<50 \mathrm{~mm}$ ) exist.

Despite the paucity of quantitative data, there appears to be general subjective agreement that many corals calcify more rapidly during early stages of

\footnotetext{
- Present address: Netherlands Institute for Sea Research (NIO2), P.O. Box 59, 1790 AB Den Burg, Texel, Netherlands
}

growth immediately (possibly up to a few years) after planular settling, than at an older age (Connell 1973, Buddemeier \& Kinzie 1976). Comparisons between juvenile and adult growth, however, have been interpreted variously because growth has been measured as different parameters: absolute or relative growth of length, surface area, volume or weight, or isotope uptake (Stephenson \& Stephenson 1933, Goreau \& Goreau 1960, Connell 1973). Moreover, in most coral species, colony morphology changes during their lifetime. Another problem is that maximum growth potential in situ is only found if coral growth is not hampered by environmental perturbation. Physical factors, spatial competition and biological depredation may disturb coral growth frequently but their importance is not well documented for juvenile corals. In ecological studies, biological interactions are often classified as either disturbance or competition (Dayton 1971, Karlson 1983). In this paper the term 'disturbance' is used to indicate all cases of physical and biological interference (including competition) of the growth process apart from cases resulting in mortality. 
In this investigation, juveniles of Agaricia species and their surrounding substratum were studied for $1 \mathrm{yr}$, by means of underwater photography. This retrospective approach yielded information, not anticipated at the beginning of the investigation, on the nature and importance of disturbance, fission and fusion processes, as well as on growth rates. In Agaricia it is especially attractive to study the relation between colony size and growth because large colonies frequently retain the 2 -dimensional plate-like growth form which is characteristic for most hermatypic juveniles. Agaricia species constitute the majority of all juveniles on every Caribbean coral reef where juvenile abundance has been studied (Barbados: Lewis 1974; Curaçao and Bonaire: Bak \& Engel 1979, Van Moorsel in prep.; Jamaica: Rylaarsdam 1983; St. Croix: Rogers et al. 1982, 1984; Panama: Wulff 1984).

I found significant differences in reproductive characteristics in 2 closely related Agaricia species, A. humilis Verrill and $A$. agaricites (Linnaeus) which could be explained in relation to the predictability of their habitats (Van Moorsel 1983). Unidentified agariciids are mentioned in several papers (e.g. Meyer \& Birkeland 1974, Sammarco 1980, Rylaarsdam 1983), and others (e.g. Bak \& Engel 1979) have not separated $A$. humilis and $A$. agaricites because at the time the former was considered to be only a growth form of the latter species. In the present paper qualitative and quantitative data on disturbance and growth rates of juveniles will be presented for both species in relation to size and depth.

\section{MATERIALS AND METHODS}

All data were collected using juvenile coral colonies of the species Agaricia humilis and A. agaricites. Mean diameter (see below) of the largest juvenile was
$35.3 \mathrm{~mm}$ at the start of the year of investigation. Colonies were present in a transect between 5 and $23 \mathrm{~m}$ depth on the fringing reef of Curaçao, Netherlands Antilles (Fig. 1). For a description of this reef and its zonation see Bak (1977) and Van den Hoek et al. (1978).

Within the transect, I chose 20 substratum patches (often dead or partly dead Montastrea cavernosa (Linnaeus) colonies) which contained one or more Agaricia colonies. Each patch was marked with a small underwater float and nails painted fluorescent red. From these nails the position of all nearby juveniles was recorded by means of triliniation. The procedure resulted in a total sample of 166 corals. At the start of the investigation, I was unaware that 2 different species, $A$. humilis and $A$. agaricites, were involved. The difference was discovered during a concurrent study on reproductive strategies of these corals (Van Moorsel 1983). Consequently, no attempt was made to select equal numbers of each species at all depths. Characteristics used to identify the species are mentioned in Van Moorsel (1983).

I used a Nikonos III camera with strobe (Philips PUF 060) and 1:2 extension tube with focal frame to photograph each coral. Each $35 \mathrm{~mm}$ slide (Kodak Ektachrome 64) represented an area of $72 \times 48 \mathrm{~mm}$. Coral code and day number were included in the subject field. In situ photography has the advantage that it does not interfere with disturbance and growth by experimental manipulation. The photographic procedure was repeated 6 times during 1 yr on the following dates: in 1979, Sep 26-Oct 5, Dec 3-5; in 1980, Jan 22-31, Mar 26-Apr 14, Jul 3-4, Sep 24-25. Minimum time interval between censuses of individual corals was 49 d. During the year, 8 additional corals were included in the sample to supply more growth data.

For the analyses, slides were projected onto paper,

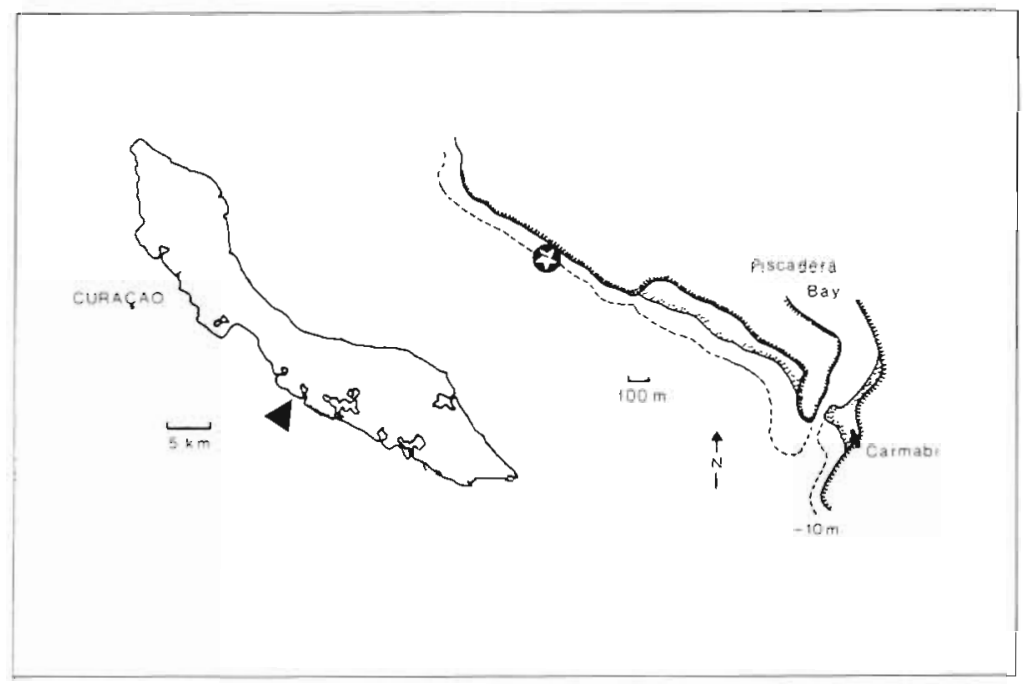

Fig. 1. Location of investigation transect (starred) near Caribbean Marine Biological Institute (Carmabi), Curaçao, Netherlands Antilles 


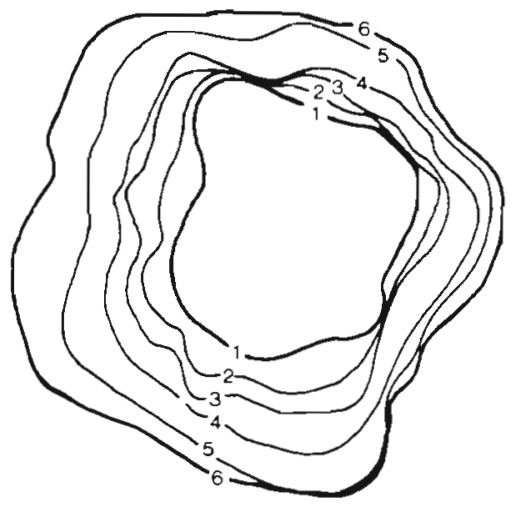

$\begin{array}{cccc}\text { Census } & \bar{\theta} & \text { Interval } & \text { Growth } \\ & \mathrm{mm} & 0 & \mu \mathrm{d}^{-1} \\ 1 & 19.0 & 67 & 44.6 \\ 2 & 22.0 & 50 & 444 \\ 3 & 24.2 & 64 & 500 \\ 4 & 275 & 99 & 50.6 \\ 5 & 325 & 83 & 33.6 \\ 6 & 35.2 & & \end{array}$

Fig. 2. Agaricia humilis. Subsequent contours of corals. Top: juvenile colony which grew undisturbed during all time intervals. Bottom: large juvenile in which growth was severely disturbed during interval $4-5$ by the sponge Reniera carmabi. Bar depicts $10 \mathrm{~mm}$ intervals. Tables list corresponding mean diameters $(\bar{\varnothing})$ and growth of $\bar{\varnothing}$

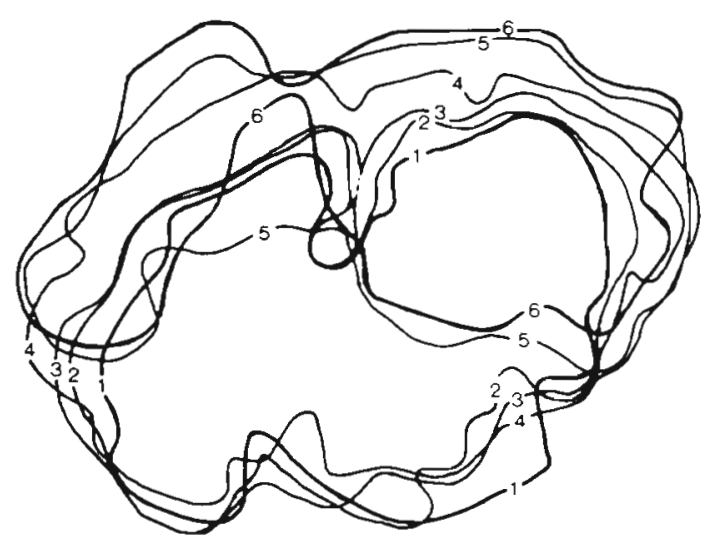

$\begin{array}{cccc}\text { Census } & \begin{array}{c}\bar{\theta} \\ \mathrm{mm}\end{array} & \begin{array}{c}\text { Interval } \\ \mathrm{d}\end{array} & \begin{array}{c}\text { Growth } \\ \mu \mathrm{m} \mathrm{d}^{-1}\end{array} \\ 1 & 325 & & \\ 2 & 33.7 & 68 & 17.4 \\ 3 & 35.5 & 50 & 36.1 \\ 4 & 38.4 & 6.4 & 45.5 \\ 5 & 31.9 & 99 & -65.5 \\ 6 & 306 & 83 & -16.2\end{array}$

on which contours of the corals were drawn (scale $2.7 \times$ actual size). I projected successive slides of the same coral on 1 sheet in the same position and orientation, using information surrounding the coral (e.g. boring sponges or dead Montastrea cavernosa calices) or polyp configuration of the Agaricia juveniles. For an example see Fig. 2.

Using the 6 subsequent contours, other information on the slides, and additional field notes, I determined for each coral whether it grew with or without discernible disturbance, or died, during each of the 5 time intervals. The procedure did not distinguish undisturbed corals from corals which experienced a disturbance and regenerated before the end of the interval. However, considering the slow regeneration from even minor superficial lesions in Agaricia agaricites (Bak \& Steward-Van Es 1980, Bak 1983), there must have been very few unrecorded disturbances between 2 successive censuses. If possible, the cause of disturbance or mortality was noted. Corals covered by only a few grains of sediment were listed as undisturbed.

All corals were placed in 1 of 3 categories according to the degree of disturbance: undisturbed (during all 5 successive intervals); disturbed (at least once); died in the course of the whole investigation period. Interac- tions between species, size, depth and disturbance were analysed in two 3-way contingency tables. The analyses were based on log linear models and significance was compared with Freeman-Tukey deviates (Sokal \& Rohlf 1981).

The slide sequences were also used to quantify the frequency of intracolony as well as intercolony fission and fusion.

As in all juvenile Agaricia, the corallum had a 2dimensional structure: the surface area was easily determined using a digitizer (Hewlet Packard 9874A) and computer (HP 9835A) with morphometric program. From these areas a mean diameter of each coral surface was determined by

$$
\varnothing=\frac{2}{s} \sqrt{\frac{A}{\pi}}
$$

where $\mathrm{A}=$ coral surface measured with digitizer and $\mathrm{s}=$ scale at which the coral was drawn. $\bar{\varnothing}$ can be defined as the diameter of a circle with the same surface area as the coral. This index of linear dimension converted from surface area is more reliable than direct measurement (Yamaguchi 1983). Daily absolute growth during an interval was calculated using

$$
\left[\bar{\varnothing}_{2}-\bar{\varnothing}_{1}\right] /\left[t_{2}-t_{1}\right]
$$


where $\bar{\varnothing}_{1}$ and $\bar{\varnothing}_{2}=$ mean diameters at day numbers $\mathrm{t}_{1}$ and $\mathrm{t}_{2}$.

For statistical methods employed consult Sokal \& Rohlf (1981) and/or Siegel (1956).

\section{RESULTS}

Between 5 and $10 \mathrm{~m}$ depth, $99 \%$ of the 100 juvenile colonies found for this study belonged to Agaricia humilis. Between 12 and $23 \mathrm{~m}$ depth the sample contained 66 juveniles, $71 \%$ belonging to $A$. humilis and $29 \%$ to $A$. agaricites. The observed difference in relative abundance of the juveniles of the 2 species parallels an important reef characteristic: a depth of 10-12 m equals the location of the 'drop off', an abrupt increase in depth (Bak 1977). The extreme scarcity of juvenile $A$. agaricites on the shallow reef makes it feasible to compare $A$. agaricites and $A$. humilis juveniles from the deep reef $(>11 \mathrm{~m})$ only. In $A$. humilis an inter-depth $(>11 \mathrm{~m}$ vs $<11 \mathrm{~m})$ comparison can be made.

The smallest size classes of Agaricia humilis were most common. This is reflected in a size distribution which is skewed to the left. This phenomenon was more pronounced in shallow juveniles than in deep juveniles (Fig. 3). Conceivably, coral size can show a relation to the degree of disturbance as well as to depth and species. Therefore, I decided to discriminate between 2 size classes. Small and large juveniles had mean diameters of $<15 \mathrm{~mm}$ or $>15 \mathrm{~mm}$ at the beginning of the investigation. This size distinction was chosen to obtain sufficient numbers in both size categories.

A. humilis

A. agaricites
The factors disturbance, size, and depth in Agaricia humilis (Table 1) and disturbance, size, and species in deep (>11 m) corals (Table 2) showed non-significant 3 -way interactions. Relatively large Freeman-Tukey deviates were only found for the mortality in large $A$. humilis at the deep reef. This was probably caused by the low values of observed $(0 \%)$ and expected mortality. It was not considered large enough to impede tests for 2-factor interactions.

\section{Agaricia humilis: disturbance, size, and depth (Table 1)}

(a) test of independence of disturbance and size. The significant decrease in fit of the model by deletion of a disturbance-size interaction term indicates that these 2 factors are not independent at each level of the factor depth. Small Agaricia humilis corals had a higher mortality than larger juveniles.

(b) test of independence of disturbance and depth. The increase of the G-value as a result of dropping the disturbance vs depth interaction term was very significant. Shallow Agaricia humilis corals had a high mortality and low rate of undisturbed growth, whereas for deep colonies the reverse was true.

(c) test of independence of size and depth. As suggested earlier, size and depth are not independent given the level of disturbance. In 'disturbed' Agaricia humilis at the shallow reef the number of small corals was higher than expected, and at the deep reef large corals were relatively abundant.
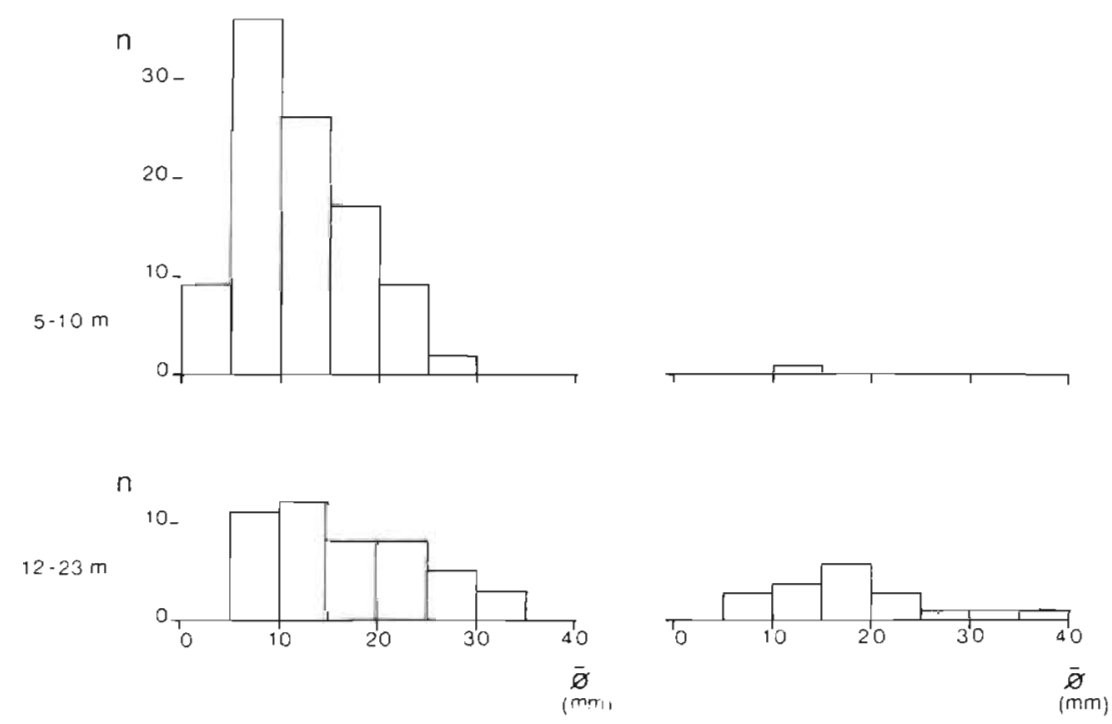

Fig. 3. Agaricia humilis and A. agaricites. Size distribution of juvenile colonies at different depths at the start of the investigation year. n: number of colonies; $\bar{\varnothing}$ : mean diameter $15 \mathrm{~mm}$ categories) 
Table 1. Agaricia humilis. 3-way contingency table, with depth, size, and disturbance, followed by 3-way analyses of frequencies. Interaction and independence expressed as G-values. Degrees of freedom in square brackets. Freeman-Tukey (F-T) deviates are listed if their absolute value is almost equal to or more than c (an approximate criterion for being large). "F-T deviates deduced from similarly marked value in contingency table; $\bar{\varnothing}$ : mean colony diameter

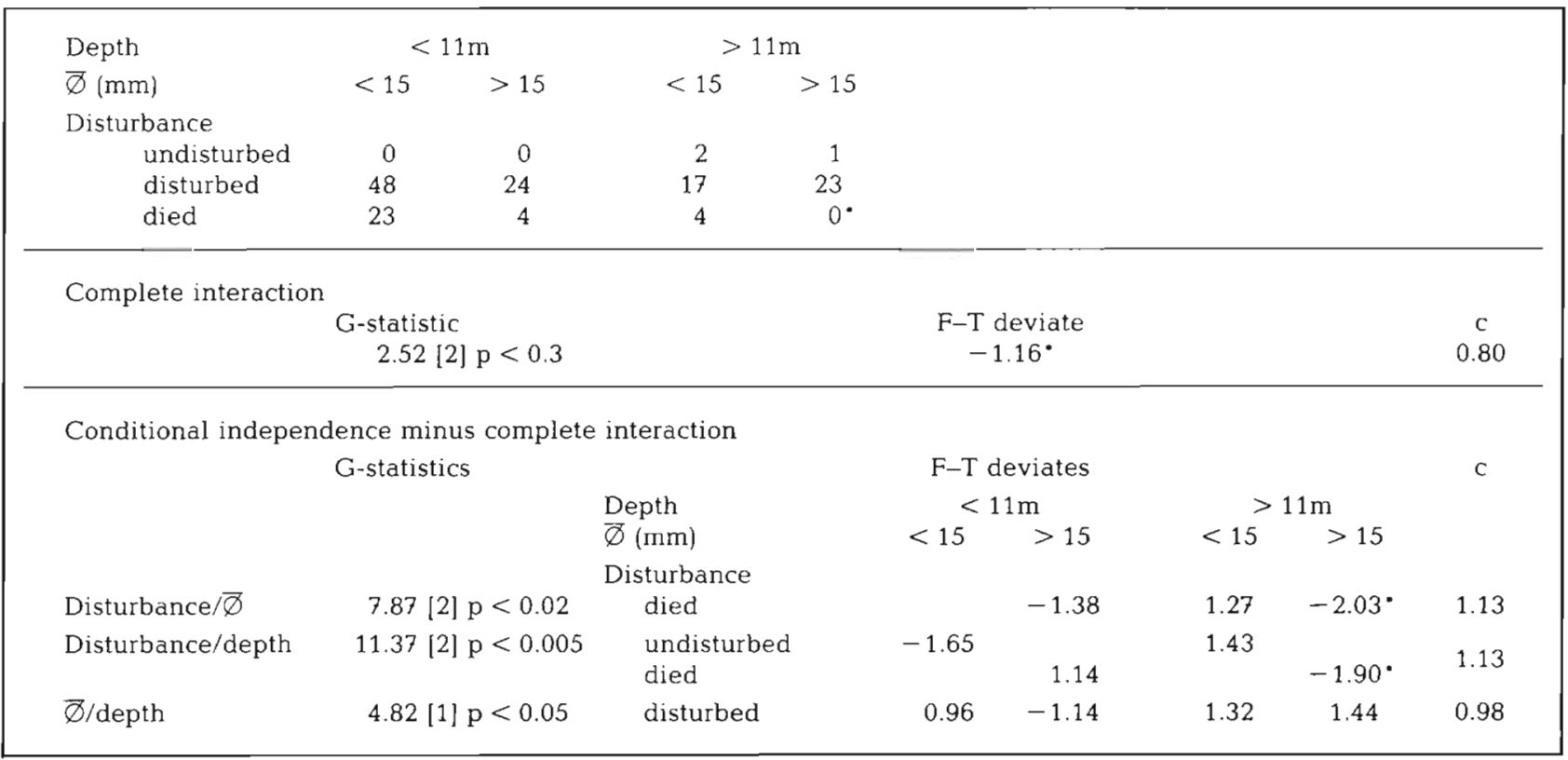

Deep Agaricia (>11 m): disturbance, size, and species (Table 2)

(a) test of independence of disturbance and size. Deletion of this term caused a non-significant drop in the fit of the model. However, Freeman-Tukey deviates for Agaricia humilis (the same as in Table 1) suggest that small corals have a higher mortality than larger juveniles.

(b) test of independence of disturbance and species. This test showed the strongest pairwise association. There was a lower number of undisturbed Agaricia humilis than expected, as opposed to a relative high number of undisturbed $A$. agaricites colonies.

Table 2. Agaricia humilis and A. agaricites. 3-way contingency table with species, size and disturbance at $>11 \mathrm{~m}$ depth, followed by 3 -way analysis of frequencies. For other information cf. Table 1.

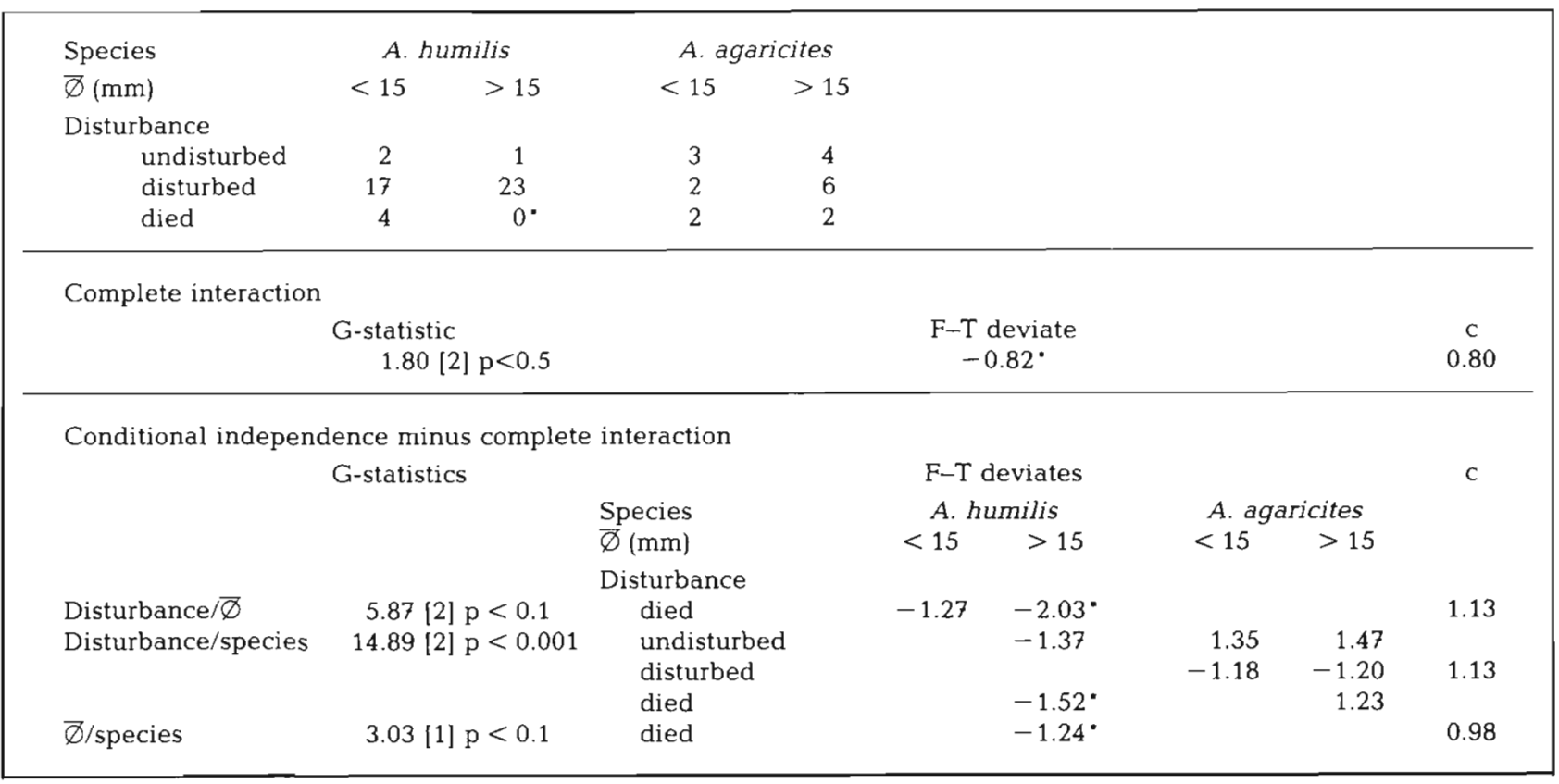


Table 3. (a) Disturbance and mortality in Agaricia humilis at 5 to $10 \mathrm{~m}(<11 \mathrm{~m})$ and at 12 to $23 \mathrm{~m}(>11 \mathrm{~m})$, and in A. agaricites at 12 to $23 \mathrm{~m}(>11 \mathrm{~m})$. Disturbing factors listed at left. \%: relative frequency; $\mathrm{n}$ : actual frequency

\begin{tabular}{|c|c|c|c|c|c|c|c|c|c|c|c|c|}
\hline & \multicolumn{6}{|c|}{ Disturbance } & \multicolumn{6}{|c|}{ Mortality } \\
\hline & \multicolumn{2}{|c|}{$\begin{array}{l}\text { A. hum } \\
<11 \mathrm{~m}\end{array}$} & \multicolumn{2}{|c|}{$\begin{array}{l}\text { A. hum } \\
>11 \mathrm{~m}\end{array}$} & \multicolumn{2}{|c|}{$\begin{array}{l}\text { A. aga. } \\
>11 \mathrm{~m}\end{array}$} & \multicolumn{2}{|c|}{$\begin{array}{l}\text { A. hum. } \\
<11 \mathrm{~m}\end{array}$} & \multicolumn{2}{|c|}{$\begin{array}{l}\text { A. hum. } \\
>11 \mathrm{~m}\end{array}$} & \multicolumn{2}{|c|}{$\begin{array}{l}\text { A. aga. } \\
>11 \mathrm{~m}\end{array}$} \\
\hline & $\%$ & $\mathrm{n}$ & $\%$ & $\mathrm{n}$ & $\%$ & $\mathrm{n}$ & $\%$ & $\mathrm{n}$ & $\%$ & $n$ & $\%$ & $\mathrm{n}$ \\
\hline Filamentous algae & 53 & 38 & 20 & 8 & 13 & 1 & 22 & 6 & & & 25 & 1 \\
\hline Crustose coralline algae & 22 & 16 & 10 & 4 & & & 7 & 2 & 50 & 2 & & \\
\hline Endolithic algae & 4 & 3 & 8 & 3 & 13 & 1 & 15 & 4 & & & & \\
\hline Gypsina & 6 & 4 & 10 & 4 & & & & & & & & \\
\hline Reniera carmabi & & & 10 & 4 & 13 & 1 & & & & & & \\
\hline Bryozod & & & 3 & 1 & & & & & & & & \\
\hline Trididemnum solidum & 1 & 1 & 3 & 1 & & & & & & & & \\
\hline Millepora & & & 3 & 1 & & & & & 25 & 1 & & \\
\hline Lebrunia coralligens & & & & & & & 4 & 1 & & & & \\
\hline Madracis & & & 3 & 1 & & & & & & & 25 & 1 \\
\hline Agaricia humilis & 1 & 1 & & & & & & & & & & \\
\hline Agaricia agaricites & 3 & 2 & & & 13 & 1 & & & & & & \\
\hline Montastrea cavernosa. & 3 & 2 & & & & & 11 & 3 & & & & \\
\hline Meandrina meandrites & 1 & 1 & & & & & 4 & 1 & & & 25 & 1 \\
\hline Isophyllastrea rigida" & 1 & 1 & & & & & 4 & 1 & & & & \\
\hline Cliona caribbaea" & & & & & & & 15 & 4 & & & 25 & 1 \\
\hline Cliona laticavicola. & & & & & & & 4 & 1 & & & & \\
\hline Coralliophila abbreviata & & & 3 & 1 & & & & & & & & \\
\hline Sediment & 1 & 1 & 23 & 9 & 25 & 2 & & & & & & \\
\hline Scar & 1 & 1 & & & 25 & 2 & & & & & & \\
\hline Part missing & 1 & 1 & 8 & 3 & & & 7 & 2 & 25 & 1 & & \\
\hline$?$ & & & & & & & 4 & 1 & & & & \\
\hline$?$ & & & & & & & 4 & 1 & & & & \\
\hline & & - & & - & & - & & - & & - & & 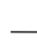 \\
\hline Total & & 72 & & 40 & & 8 & & 27 & & 4 & & 4 \\
\hline
\end{tabular}

Table 3. (b) Disturbance in A. humilis and A. agaricites expressed as $\mathrm{n}$. (Includes 1 A. agaricites colony $<11 \mathrm{~m}$ (not in Table $3 \mathrm{a}$ ) which contributes 1 to 'Others'.) G-statistics ( $G_{a d}$ : G-value adjusted with Williams' correction) are obtained from tests of independence, for factors in $2 \times 2$ tables, for 'Total' from $\mathrm{R} \times \mathrm{C}$ table

\begin{tabular}{|c|c|c|c|}
\hline & $<\underset{\mathrm{n}}{\mathrm{A}} \mathrm{m}$ & $>11 \mathrm{~m}$ & $\mathrm{G}_{\mathrm{adj}}$ \\
\hline Filamentous algae & 38 & 9 & $14.1[1] p<0.001$ \\
\hline Crustose coralline algae & 16 & 4 & $4.1[1] \mathrm{p}<0.05$ \\
\hline Encrusting animals & 5 & 11 & $6.2[1] \mathrm{p}<0.025$ \\
\hline Sediment & 1 & 11 & $15.3[1] p<0.001$ \\
\hline Others & 13 & 13 & 1.4 [1] ns \\
\hline & - & - & \\
\hline Total & 73 & 48 & $32.7[4] p<0.001$ \\
\hline
\end{tabular}

(c) test of independence of size and species. This resulted in a non-significant increase of the G-value. The only Freeman-Tukey deviate that indicated that size and species cannot be considered completely independent at each level of disturbance was based on the above mentioned low mortality value of large Agaricia humilis $>11 \mathrm{~m}$.

Conclusions: Small Agaricia humilis juveniles have a higher mortality than larger ones. Shallow $A$. humilis corals have a high mortality and the frequency of 

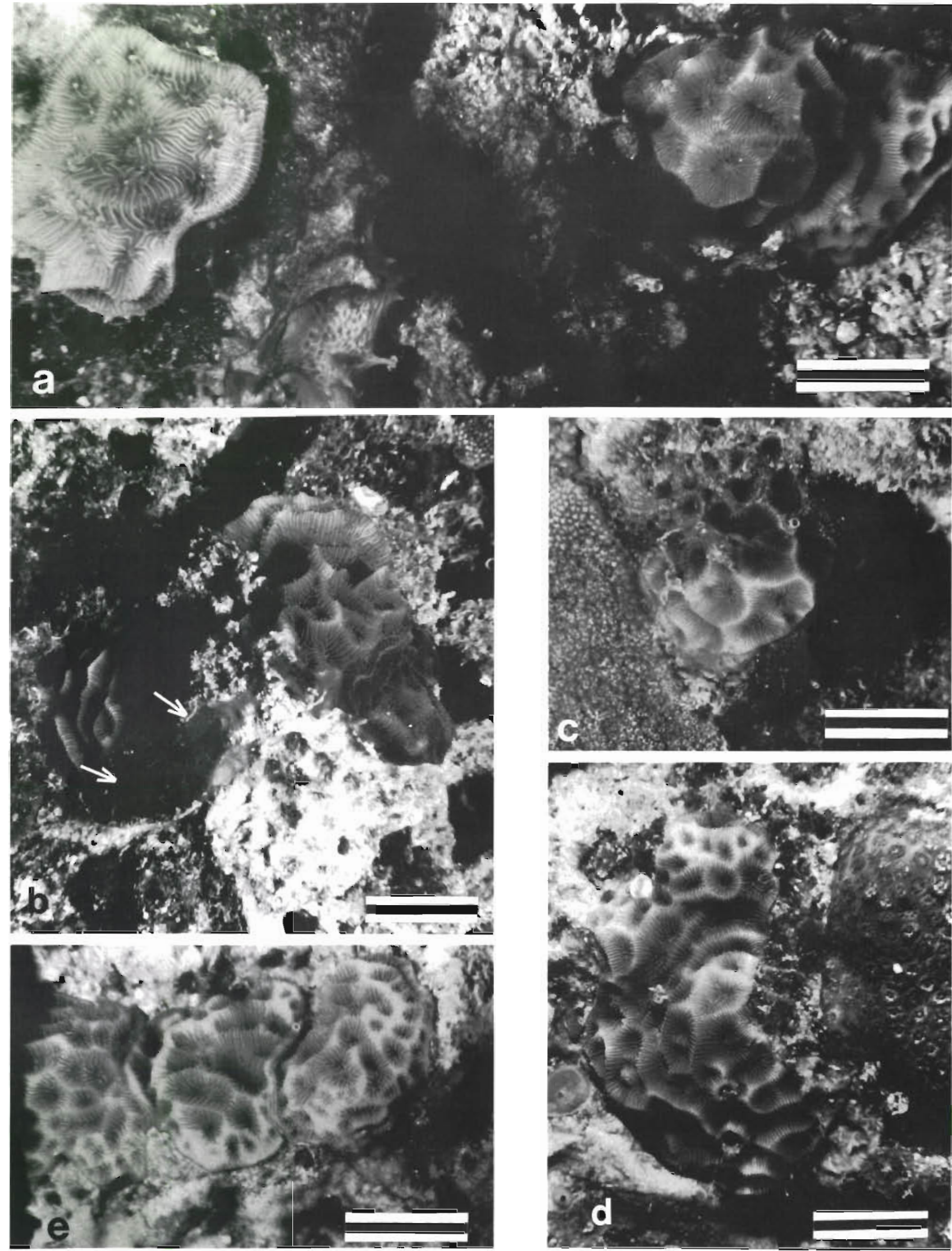

Fig. 4 (a) Agaricia agaricites (left) with typical edge, elevated over the substratum, and A. humilis (right) in sediment covered by Cyanophyceae. (b) A. humilis. Overgrowth of colony by sponge Reniera carmabi (arrows). The lower part of the colony has been killed by the sponge in previous months. (c) A. humilis. Disturbance of upper part by endolithic algae. (d) A. humilis, partly killed by Madracis colony (right). (e) A. humilis. Intercolony fission; between colonies a distinct suture is visible. Scale bars $=10 \mathrm{~mm}$ 
undisturbed corals is low in comparison with $\operatorname{deep} A$. humilis corals. Large $A$. humilis juveniles are relatively uncommon at shallow locations compared to the deep reef. The largest difference in disturbance between $A$. humilis and $A$. agaricites $(>11 \mathrm{~m})$ is the higher number of undisturbed corals in the latter.

\section{Causes of disturbance and mortality}

For each juvenile colony, it was determined which factor contributed most to disturbance or mortality in the course of the whole investigation year (Table 3a). The effect of some of these factors on juveniles is depicted in Fig. 4 a to d.

Within the corals listed as disturbed there was a significant difference in the relative importance of the disturbing factors in relation to depth $(\mathrm{p}<0.001, \mathrm{R} \times \mathrm{C}$ test of independence, see Table $3 b$ ). Overgrowth by filamentous and crustose coralline algae contributed $74 \%$ to the total disturbance at shallow depth $(<11 \mathrm{~m})$, which is much more than in deeper juveniles $(27 \%$, $>11 \mathrm{~m})$. In combination this difference is significant at the $0.1 \%$ level. In the deeper group, especially sediment (Fig. 4a) was more important as a disturbing factor. The strong difference in disturbance by sediment resulted in the highest G-value (Table 3b). The overgrowth by non-coelenterate encrusting animals, Gypsina sp., Reniera carmabi Van Soest, Bryozoa and Trididemnum solidum (Van Name), was more important at the deep reef; the depth-related effect of Reniera carmabi (Fig. 4 b) was especially significant ( $\mathrm{p}=$ 0.009 , Fisher's exact test of independence).

In Table 3a, a distinction has been made between cases of abrupt and gradual mortality. In the former cases, corals disappeared between 2 subsequent censuses (interval time 50 to $98 \mathrm{~d}$ ), and in the latter cases, the living coral surface diminished over several intervals prior to death. The cause of mortality could not be traced in 2 of the total of 35 cases. Mortality was abrupt in $34 \%$ of the cases. In $50 \%$ of these cases substratum condition suggested weakening of the coral substratum attachment by boring sponges $(5$ times by Cliona caribbaea Carter and once by C. Iaticavicola Pang) sometimes in combination with endolithic (= boring) algae. In at least 3 cases where boring sponges were listed as the most important cause of mortality, the actual event (proximate cause) of disappearance was probably related to the activity of grazing organisms. The other $50 \%$ were aggressive interactions with other corals: 3 with Montastrea cavernosa, 2 with Meandrina meandrites (Linnaeus) and 1 with Isophyllastrea rigida (Dana). In cases of gradual mortality $(60 \%)$, the most important causes were filamentous and endolithic algae, especially at the shallow reef, where these factors were responsible for 40 and $27 \%$ respectively of these mortality cases $(\mathrm{n}=15)$.

The relative importance of endolithic algae (Fig. 4c) at the shallow reef, in non-lethal disturbance as well as in mortality, is somewhat underestimated. They often acted simultaneously or successively with factors which were considered to be more important. The gastropod coral predator Coralliophila abbreviata Lamarck and the sea anemone Lebrunia coralligens (Wilson) were encountered at the borders of $5 \%$ and $14 \%$ respectively, of all Agaricia colonies $(\mathrm{n}=166)$ but in only 2 cases were they classified as most important factor contributing to disturbance or mortality.

\section{Fission and fusion}

Fission and fusion processes are considered separately as intracolony and intercolony phenomena (Fig. 5). In intracolony cases, 2 or more parts of 1 colony split up or reunify. Tissue fusion is complete. In intercolony cases, corals of different origin are involved and adjacent corals are characterized by the presence of a distinct suture at the common perimeters (Fig. 4e).

At the start of the investigation, 5 of the 166 colonies present showed intracolony fission $(2$ or 3 parts separated by dead skeleton). After 1 yr, 6 corals consisted of 2 or more parts (Fig. 5). However, these numbers underestimate the dynamics of intracolony fission and fusion. During the investigation year 15 corals were involved: 1 Agaricia agaricites and $14 \mathrm{~A}$. humilis colonies, $50 \%$ of which were found deeper than $11 \mathrm{~m}$.

Of the original colonies, 18 showed intercolony fusion (as groups of 2 or 3 corals) at the start of the investigation period. 1 yr later, 20 juveniles participated in intercolony fusion, but only $55 \%$ of these colonies were the same as the originally fused ones (Fig. 5). Corals involved in a change of their intercolony fission or fusion status during the investigation year numbered a total of 20 . These were all Agaricia humilis colonies, 2 of which occured deeper than $11 \mathrm{~m}$.

In total, $21 \%$ of the original corals ( $\mathrm{n}=166$ ) were involved in a change of their intracolony or intercolony fusion or fission status.

\section{Growth}

Maximum growth

A frequency distribution of all data on growth inter$\mathrm{val}^{-1}$ is presented in Fig. 6. In Agaricia humilis maximum growth values interval ${ }^{-1}$ of mean diameter were $66.7 \mu \mathrm{m} \mathrm{d}^{-1}(<11 \mathrm{~m})$ and $72.0 \mu \mathrm{m} \mathrm{d}^{-1}(>11 \mathrm{~m})$, in $A$. 
Fission

including end of year
during year only
Fusion
including end of year
during year only
number of corals changing fission/tusion state

number of corals changing fission/tusion state

No change in fission/fusion state

number of corals in separated state

number of corals in fused state
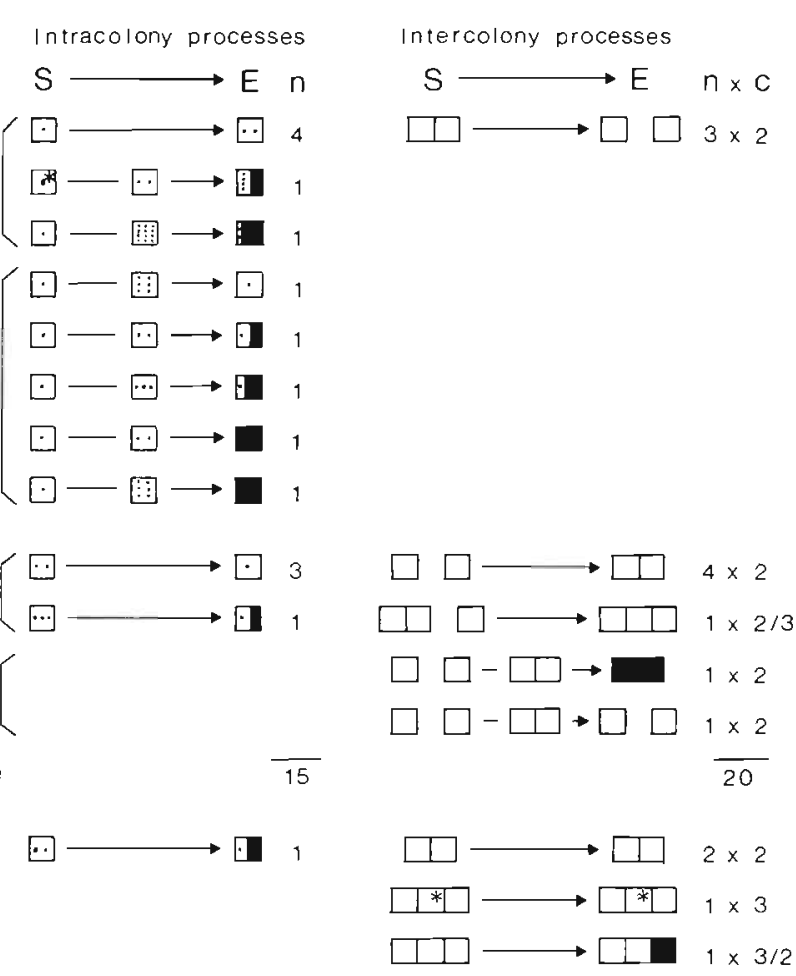

$5 \longrightarrow 6$

Fig. 5. Agaricia. Overall picture of all of the original colonies involved in intracolony and intercolony fission and fusion. " $A$. agaricites, others $A$. humilis; S, E: situations at start and end of investigation year (situations between $\mathrm{S}$ and $\mathrm{E}$ only depicted if relevant); squares: colonies (black parts: died); points (in intracolony processes): number of parts separated by dead skeleton; $\mathrm{n}$ : number of observations; $c$ : number of colonies per observation

agaricites $(>11 \mathrm{~m})$ it was $84.5 \mu \mathrm{m} \mathrm{d} \mathrm{d}^{-1}$. Based on the annual growth of real diameters (not depicted) the maximum growth of $A$. humilis was $79.9 \mu \mathrm{m} \mathrm{d}^{-1}$ and $A$. agaricites $78.3 \mu \mathrm{m} \mathrm{d} \mathrm{d}^{-1}$. Therefore, it seems safe to conclude that both coral species may show a diameter growth of $80 \mu \mathrm{m} \mathrm{d}^{-1}$ which is $29 \mathrm{~mm}$ on an annual basis.

In a few cases, radius growth (from a fixed point) was more than half of the maximum diameter growth. On a yearly basis, the maximum radius growth of $\mathrm{Agaricia}$ humilis and $A$. agaricites was $50.3 \mu \mathrm{m} \mathrm{d}^{-1}$ and $49.5 \mu \mathrm{m}$ $\mathrm{d}^{-1}$ respectively. In these cases, growth in directions other than that of the maximum radius growth was always much slower or even negative. It appears that slow growth along part of the coral's perimeter may be compensated for by 'supraoptimal' growth of another part.

\section{Mean annual growth}

Growth of mean diameter during the whole investigation year of all corals is presented in Fig. 7. Although both species have about the same maximum growth, actual annual growth is strongly influenced by the degree of disturbance. Therefore, occurrences of maximum growth $\left(80 \mu \mathrm{m} \mathrm{d}^{-1}\right)$ during the whole year were
Fig. 6. Agaricia humilis and A. agaricites. Frequency distribution of all data on growth of mean diameter per interval. Depth indication ( $>$ or $<11 \mathrm{~m}$ ), corresponds with Fig. 3. Length of bars depicts percentage of growth data exhibiting positive growth (pos.), expressed in different classes, or negative growth (neg.). Shading: white, undisturbed; hatched, disturbed. f: number of growth data
A. humilis $<11 \mathrm{~m}$

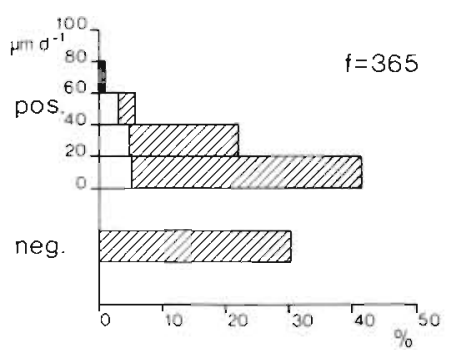

A. humilis $>11 \mathrm{~m}$

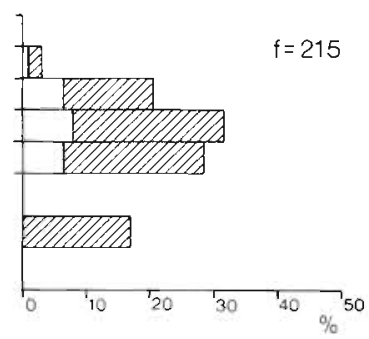

A. agaricites $>11 \mathrm{~m}$

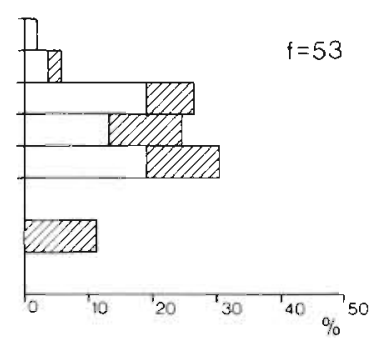



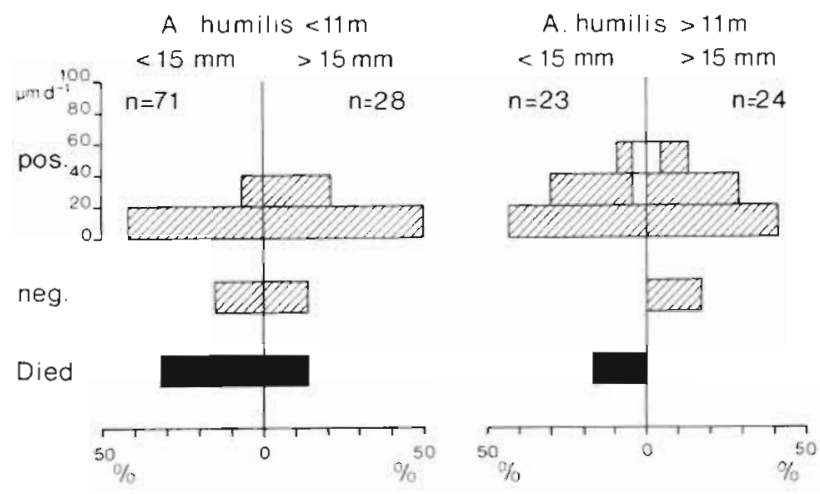

absent in shallow ( $<11 \mathrm{~m}$ ) Agaricia humilis, infrequent in deep $(>11 \mathrm{~m}) A$. humilis and common in deep $A$. agaricites. A Mann-Whitney $U$-test on the positive annual growth values indicated a significant difference $(\mathbf{p}<0.01)$ in $A$. humilis between the 2 depth ranges. Neither the difference between deep $A$. humilis and $A$. agaricites, nor the differences in annual growth between the 2 size classes, were significant.

Interval growth data (in Fig. 6) are not independent of coral sizes. For example, the fastest growing juveniles would prevail in the largest size classes more and more during the subsequent intervals as a result of their high growth rates. Fig. 7 supplies annual growth rates as function of size at the first census in the 3 species/depth categories.

\section{Seasonal growth}

Growth data obtained from intervals without disturbance are listed in Table 4 . In all intervals mean and maximum growth values of deep (>11 m) Agaricia humilis are larger than at the shallow $(<11 \mathrm{~m})$ reef. The lower maximum growth in shallow $A$. humilis compared to the deep reef may be the result of mostly

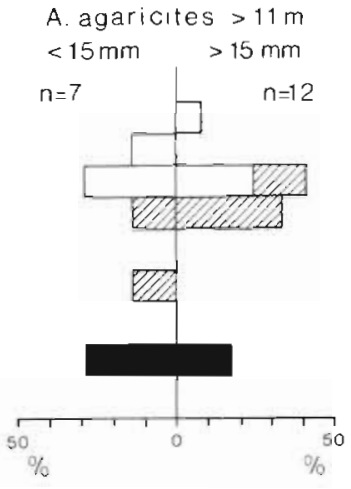

Fig. 7. Agaricia humilis and $A$ agaricites. Total annual growth separated for juvenile size (mean diameter) at the start of the investigation year: small $(<15 \mathrm{~mm})$ and Iarge (>15 mm). Depth indication corresponds with Fig. 3. Length of bars depicts percentage of colonies exhibiting positive growth (pos.) expressed in different classes, negative growth (neg.) or death. Shading: white, undisturbed; hatched, disturbed; black, died. n: number of colonies smaller sample sizes (Table 4). A comparison of growth in the 5 intervals was made by comparing only those corals in Table 4 which had 2 or more intervals with undisturbed growth. Of 10 possible comparisons between time intervals per species, only 1 showed a significant difference ( $p<0.001$, Sign test) in growth: all $A$. humilis colonies which showed undisturbed growth in Dec/Jan as well as in Feb/Mar ( $n=12)$, grew faster during the latter interval.

\section{DISCUSSION}

The depth-related difference in numerical abundance of Agaricia humilis and $A$. agaricites juveniles represents different recruitment patterns, which must be traced to settlement, fission and fusion, survival and growth. The importance of settlement will be treated elsewhere (Van Moorsel in prep.). The results in this paper have shown that the rates of disturbance and mortality of juvenile corals are related to colony size, depth, and species. I discuss first these variables (in this order), then fission and fusion, and finally growth.

Table 4. Agaricia. Mean and maximum growth per interval in colonies listed as undisturbed during intervals: in $A$. humilis at 5 to $10 \mathrm{~m}(>11 \mathrm{~m})$, and at 12 to $23 \mathrm{~m}(>11 \mathrm{~m})$ and in $A$. agaricites at 12 to $23 \mathrm{~m}(>11 \mathrm{~m})$. Growth expressed as increase of mean diameter $\left(\mu \mathrm{m} \mathrm{d} \mathrm{d}^{-1}\right)$

\begin{tabular}{|c|c|c|c|c|c|c|c|}
\hline & & Oct, Nov & Dec, Jan & $\begin{array}{c}\text { Interval month } \\
\text { Feb, Mar }\end{array}$ & Apr-Jun & JuI-Sep & Total \\
\hline $\begin{array}{l}\text { A. humilis } \\
<11 \mathrm{~m}\end{array}$ & $\begin{array}{l}\text { mean } \\
\text { max } \\
n\end{array}$ & $\begin{array}{l}36.5 \\
59.5 \\
19\end{array}$ & $\begin{array}{c}21.1 \\
46.8 \\
6\end{array}$ & $\begin{array}{l}33.5 \\
56.8 \\
11\end{array}$ & $\begin{array}{l}27.4 \\
40.4 \\
12\end{array}$ & $\begin{array}{c}34.7 \\
56.9 \\
9\end{array}$ & $\begin{array}{l}32.1 \\
59.5 \\
57\end{array}$ \\
\hline $\begin{array}{l}\text { A. humilis } \\
>11 \mathrm{~m}\end{array}$ & $\begin{array}{l}\text { mean } \\
\text { max } \\
\mathrm{n}\end{array}$ & $\begin{array}{l}40.5 \\
72.0 \\
11\end{array}$ & $\begin{array}{l}29.7 \\
55.6 \\
11\end{array}$ & $\begin{array}{l}35.5 \\
61.2 \\
15\end{array}$ & $\begin{array}{l}42.0 \\
70.1 \\
17\end{array}$ & $\begin{array}{l}38.8 \\
67.6 \\
19\end{array}$ & $\begin{array}{l}37.8 \\
72.0 \\
73\end{array}$ \\
\hline $\begin{array}{l}\text { A. agaricites } \\
>11 \mathrm{~m}\end{array}$ & $\begin{array}{l}\text { mean } \\
\max \\
\mathrm{n}\end{array}$ & $\begin{array}{l}40.8 \\
65.4 \\
11\end{array}$ & $\begin{array}{c}33.5 \\
59.2 \\
8\end{array}$ & $\begin{array}{c}26.1 \\
55.2 \\
9\end{array}$ & $\begin{array}{l}30.4 \\
62.7 \\
10\end{array}$ & $\begin{array}{c}39.2 \\
84.5 \\
8\end{array}$ & $\begin{array}{l}34.1 \\
84.5 \\
46\end{array}$ \\
\hline
\end{tabular}




\section{Size}

Bak \& Engel (1979) conducted a study on disturbance of growth and mortality of juvenile agariciids under natural circumstances on the same reef. Within the same depth range (zone I, II and III, their Table 4), $34 \%(n=195)$ were considered undisturbed in a 6 mo investigation period. If the chance of growing undisturbed is independent of coral identity and season, this value transfers to $11 \%$ as a yearly estimate of undisturbed juveniles. This is somewhat higher than my annual total of $6 \%(\mathrm{n}=166)$, but confirms the high risk agariciid juveniles face of being disturbed.

Bak \& Engel (1979) found $25 \%$ mortality in $6 \mathrm{mo}$, which is much higher than the annual $17 \%(n=166)$ in this study. This difference is largely the result of a size effect. In the former investigation, the range of initial maximum coral diameters was 2 to $20 \mathrm{~mm}$. In the present study it was 3 to $46 \mathrm{~mm}$. The higher survival of larger corals is related to the regeneration ability of corals: a certain level of disturbance which may kill a primary polyp gives a large coral (colony) an opportunity to recover. It is possible that smaller colonies have a relatively low regeneration capacity, as suggested by Connell (1973). Data on the absolute linear growth of damaged Stylophora pistillata (Esper) colonies (Loya 1976a, deduced from his Fig. 1) confirm this hypothesis.

The significant negative relation between size and mortality in Agaricia humilis in this study parallels the significant higher survival of large juveniles in Jamaica reported by Rylaarsdam (1983). The greatest diameters of her largest juveniles were $<50 \mathrm{~mm}$ and are comparable to this study, but she found a relatively high (56\%) annual mortality in Agaricia juveniles. Hughes \& Jackson (1980), working on Agaricia in Jamaica, found a lower yearly mortality $(26 \%, \mathrm{n}=$ $216)$ in a size class with maximum diameters between 10 and $100 \mathrm{~mm}$. At Heron Island, Great Barrier Reef, Connell (1973) also found a negative relation between size and mortality in a natural coral population. It appears that a careful description of size distribution is necessary in studies on juvenile scleractinian ecology.

\section{Depth}

The significant negative relation between depth and disturbance (Table 1) was not found in the study of juveniles by Bak \& Engel (1979), but they suggested that the mortality of Agaricia juveniles on the shallow reef was influenced by catastrophic occurrences beyond their 6 mo investigation. In a $5 \mathrm{yr}$ study of the Curaçaoan reef, Bak \& Luckhurst (1980) demonstrated that the highest levels of abrupt (or catastrophic) mor- tality (a process which starts and ends within an interval of 8 to $10 \mathrm{mo}$ ) of large corals (maximum diameter $>30 \mathrm{~cm}$ ) occurred at shallow depths. Table 3a seems to confirm this for juvenile $A$. humilis, but mortality was too low to demonstrate a significant difference $(\mathrm{p}=$ 0.15 , Fishers's exact test of independence).

The difference in relative frequency of factors which caused disturbance and mortality at the 2 depth ranges (Table $3 a, b$ ) is partly the result of differences in light and water movement. The considerable overgrowth by filamentous and crustose coralline algae at the shallow reef is probably the result of relatively high irradiance. Endolithic algae were important factors in disturbance and mortality throughout the transect. In Curaçao, endolithic algae are present all over the limestone reef substratum and also under much of the living tissue of corals (Wanders 1977). Deep corals suffer relatively more from sediment, even though there is less sedimentation in this environment (Bak \& Engel 1979, Van Moorsel in prep.). Due to reduced water movement, they can rely less on passive sediment clearing. Bak \& Engel (1979) did not mention endolithic algae and in their Table 5, sediment seems to be most important at the shallow reef ( 3 to $9 \mathrm{~m}$ ). However, in view of their large proportion of disturbance cases caused by unknown agents $(>50 \%$ ), it remains possible that these results are compatible with the present study. A high relative importance of overgrowth by the combination of encrusting forams, sponges, bryozoans and colonial ascidians on the deep reef was also found by Bak \& Engel (1979). This reflects their higher bottom cover in that habitat. Ott \& Lewis (1972) already observed Coralliophila abbreviata at the living margin of Agaricia and noted little damage in the field.

\section{Species}

The low mortality and high number of undisturbed colonies of Agaricia agaricites (Table 2) is to some degree the result of the growth form of this coral. All undisturbed $A$. agaricites colonies $(\mathrm{n}=7)$ showed a typical colony edge which was at least partly elevated over the substratum (Fig. 4a; Van Moorsel 1983 Fig. 1a). This is effective in avoiding submergence in shifting sediments and overgrowth by spatial competitors such as filamentous algae and encrusting organisms. A. humilis is more encrusting, the colony edge following the contour of the substratum (Fig. 4a; Van Moorsel 1983 Fig. 1a). Consequently, this species is more susceptible to becoming engulfed by other bottom components.

The high mortality of Agaricia humilis caused by Montastrea cavernosa (Table 3) can be explained by the fact that $A$. humilis is often found in dead calices of 
only partially dead colonies of this species. In such cases, re-growing $M$. cavernosa tissue constitutes a high risk. The abrupt nature of mortality near regrowing $M$. cavernosa tissue indicates that an aggressive interaction occurred, but the actual process was not observed. Since Chornesky (1983) did not observe tissue digestion in $A$. agaricites f. purpurea and $\mathrm{f}$. carinata by $M$. cavernosa, this might indicate that $A$. humilis is less able to defend itself. I have not observed aggressive interactions between $A$. agaricites and $A$. humilis.

\section{Fission and fusion}

Fission and fusion have been investigated by Hughes \& Jackson (1980) in colonies of Agaricia agaricites, A. lamarcki Milne Edwards \& Haime and Leptoseris cucullata (Ellis \& Solander). They described only intracolony processes. In $1 \mathrm{yr}, 6 \%$ of all colonies ( $n=662$, largest diameter $500 \mathrm{~mm}$ ) changed fission or fusion status. Their percentage is derived from a data set in which separate fragments of 1 original colony were given colony status. If this practice is used on intracolony fission and fusion data in the present study ( $n=166$ becomes 172 ), a similar figure ( $8 \%$ ) is found, but only if it is also solely derived from data at the start and end of the investigation year. The incorporation of data derived during the $1 \mathrm{yr}$ investigation period as well as data on intercolony processes results in a significantly higher value of $21 \%$, which indicates a much more dynamic picture $(\mathrm{p}<0.001, \mathrm{G}$-test of independence). In their study of the Curaçaoan reef, Bak \& Luckhurst (1980) came to an analogous conclusion: coral cover was very constant over the 5 yr study period but spatial rearrangements, recorded at 8 to $10 \mathrm{mo}$ intervals, outlined a community pattern that was surprisingly variegated through time.

\section{Growth}

The perimeter/surface area ratio of a unifacial platelike coral will decrease with increasing size. If growth is restricted to the perimeter, and energy input into the growth process is proportional to surface area, absolute linear growth will be proportional to coral diameter. However, this study showed that absolute linear growth is independent of juvenile size. Maximum diameter growth of $80 \mu \mathrm{m} \mathrm{d}^{-1}$ in Agaricia humilis and A. agaricites agrees quite well with $76 \mu \mathrm{m} \mathrm{d}^{-1}$ in Agaricia juveniles as determined by Bak \& Engel (1979). Large $A$. agaricites corals, with the same essentially 2-dimensional appearance of a juvenile have a maximum growth of $68 \mu \mathrm{m} \mathrm{d}^{-1}$ (Bak 1976). These are strong indicators of constant absolute linear growth. I hypothesize that diameter growth drains energy only from a restricted zone, of a certain width, along the coral's perimeter. In this case, absolute linear coral growth of plate-like corals can be expected to be independent of size.

This hypothesis could be extended also to other species and growth forms. In his growth study of medium sized corals, Maragos (1972) found no size effect on growth rates when expressed as radius increase. The same result is obtained if data on maximum increase of surface area of smallest and largest corals (Acropora) in Connell (1973, Fig. 1a) are converted to diameter increase. If linear growth is constant, relative growth as a function of size or weight diminishes automatically. This was already found by Stephenson \& Stephenson (1933), who used relative linear and area measurements, and by Goreau \& Goreau (1960), who used relative calcification. Yamaguchi (1983) used a Gompertz growth curve to fit the data of the branching coral Pocillopora damicornis (Linnaeus) supplied by Stephenson \& Stephenson (1933). Although the fit is good, the age/size relationship (his Fig. 2) strongly suggests constant linear growth within the size range for which the original growth data were collected. Loya (1976b) found the branching coral Stylophora pistillata to grow proportionally slower as it aged, but in absolute terms growth was constant. The increase of his smallest size group was even significantly less than the larger groups. This might be explained by the relatively more massive growth form of the smallest size group. Constancy of linear growth has also been found in large massive corals through sclerochronology, in which annual growth bands present in these corals are used as recorders of environmental history (Buddemeier \& Kinzie 1976, Highsmith 1979, Shinn 1981). Constant absolute linear growth during all life phases appears to be the rule rather than the exception in Scleractinia.

In Agaricia humilis, annual growth is less in shallow $(<11 \mathrm{~m})$ colonies than in deep colonies. However, growth measurements over short intervals clearly demonstrated that potential growth rates are not significantly different. More frequent disturbance in shallow juveniles was responsible for the difference in annual growth. To find constant growth with increasing depth (= decrease in irradiance) is not exceptional). The relation between growth and depth is negative in some species but positive in others (cf. review in Oliver et al. 1983). In large $A$. agaricites, Bak (1976) found a greater calcification per unit tissue area (mass increase) at $24 \mathrm{~m}$ than at $13 \mathrm{~m}$ depth. At $13 \mathrm{~m}, A$. agaricites forms bifacial lobes, which have a relatively low ratio between length of growth perimeter and coral surface area, compared to the $24 \mathrm{~m}$ specimens which had unifacial surfaces. Assuming that, in both 
forms, the perimeter is the main site of growth, relative calcification can vary with depth in spite of constant linear growth. Radial extension is only 1 parameter of calcification. Only when other parameters (cf. Oliver et al. 1983) are available can we better understand the growth of plate-like corals.

The high disturbance level of the shallow reef resulted in an effective low growth rate as well as a high mortality (often abrupt) of shallow juveniles. Therefore, a high proportion of these corals remain in the small size categories. Agaricia humilis is adapted to this situation by reaching sexual maturity at a small size (maximum diameter $28 \mathrm{~mm}$ ) and by other characteristics which indicate a relatively high energy allocation to reproduction (Van Moorsel 1983). At the deep reef, spatial competition and sediment will become increasingly important. A. agaricites has the more advantageous growth form to face such adverse factors. Small $A$. agaricites probably put more energy into the maintainance of their growth form as they start reproducing at a much larger size (maximum diameter $108 \mathrm{~mm}$ ) than A. humilis (Van Moorsel 1983).

Acknowledgements. The Caribbean Marine Biological Institute (Carmabi), Curaçao provided research facilities. The help of staff, diving assistants, other personnel and students during my stay at Carmabi is gratefully acknowledged. I thank Dr. R. P. M. Bak for supervision during all phases of the investigation. Dr. R. W. M. Van Soest enabled me to prepare the manuscript at the Institute of Taxonomic Zoology, Amsterdam. Dr. J. J. Videler provided facilities for measuring coral surfaces. C. Streefkerk and M. Streefkerk helped with computer analyses. Dr. J. C. Jager and J. Th. L. Jong gave statistical advices. Professor Dr. I. R. Ball, Professor Dr. G. P. Baerends, $F$. Van Duyl and 2 anonymous reviewers read the manuscript and offered valuable suggestions.

This investigation was supported by a grant from the Netherlands Foundation for the Advancement of Tropical Research (WOTRO) W84-167

\section{LITERATURE CITED}

Bak, R. P. M. (1976). The growth of coral colonies and the importance of crustose coralline algae and burrowing sponges in relation with carbonate accumulation. Neth. J. Sea Res. 10: 285-337

Bak, R. P. M. (1977). Coral reefs and their zonation in the Netherlands Antilles. Am. Ass. Pet. Geol. Stud. Geol. 4: 3-16

Bak, R. P. M. (1983). Neoplasia, regeneration and growth in the reef building coral Acropora palmata. Mar. Biol. 77: 221-227

Bak, R. P. M., Engel, M. S. (1979). Distribution, abundance and survival of juvenile hermatypic corals (Scleractinia) and the importance of life history strategies in the parent coral community. Mar. Biol. 54: 341-352

Bak, R. P. M., Luckhurst, B. E. (1980). Constancy and change in coral reef habitats along depth gradients at Curaçao. Oecologia (Berl.) 47: 145-155

Bak, R. P. M., Steward-Van Es, Y. (1980). Regeneration of superficial damage in the scleractinian corals Agaricia agaricites f. purpurea and Porites astreoides. Bull. mar. Sci. 30: 883-887

Buddemeier, R. W., Kinzie III, R. A. (1976). Coral growth. Oceanogr. mar. Biol. A. Rev. 14: 183-225

Chornesky, E. A. (1983). Induced development of sweeper tentacles on the reef coral Agaricia agaricites: a response to direct competition. Biol. Bull. mar. biol. Lab., Woods Hole 165: 569-581

Connell, J. H. (1973). Population ecology of reef building corals. In: Jones, O. A., Endean, R. (ed.) Biology and geology of coral reefs, Vol. 2. Academic Press, New York, p. $205-245$

Dayton, P. K. (1971). Competition, disturbance, and community organization: the provision and subsequent utilization of space in a rocky intertidal community. Ecol. Monogr. 41: $351-389$

Goreau, T. F., Goreau, N. I. (1960). The physiology of skeleton formation in corals III. Calcification rate as a function of colony weight and total nitrogen content in the reef coral Manicina areolata (Linnaeus). Biol. Bull. Mar. biol. Lab., Woods Hole 118: 419-429

Highsmith, R. C. (1979). Coral growth rates and environmental control of density banding. J. exp. mar. Biol. Ecol. 37 : $105-125$

Hughes, T. P., Jackson, J. B. C. (1980). Do corals lie about their age? Some demographic consequences of partial mortality, fission and fusion. Science, N.Y. 209: 713-715

Karlson, R. H. (1983). Disturbance and monopolization of a spatial resource by Zoanthus sociatus (Coelenterata, Anthozoa). Bull. mar. Sci. 33: 118-131

Lewis, J. B. (1974). Settlement and growth factors influencing the contagious distribution of some Atlantic reef corals. In: Cāmeron, A. M., Campbell, B. M., Cribb, A. B., Endean, R., Jell, J. S., Jones, O. A., Mather, P., Talbot, F. H. (ed.) Proc. 2nd Intl Symp. cor. reefs, Vol. 2. The Great Barrier Reef Committee, Brisbane, p. 201-206

Loya, Y. (1976a). Skeletal regeneration in a Red Sea scleractinian coral population. Nature, Lond. 261: 490-491

Loya, Y. (1976b). The Red Sea coral Stylophora pistillata is an $r$ strategist. Nature, Lond. 259: 478-480

Maragos, J. E. (1972). A study of the ecology of Hawaiian reef corals, Ph. D. thesis, University of Hawaii

Meyer, D. L., Birkeland, C. (1974). Marine studies. In: Rubinoff, R. W. (ed.) Environmental monitoring and baseline data compiled under the Smithsonian Institution environmental sciences program. Smithsonian Trop. Res. Inst., Washington D. C., p. 134-137, 242, 250

Oliver, J. K., Chalker, B. E., Dunlap, W. C. (1983). Bathymetric adaptations of reef-building corals at Davies Reef, Great Barrier Reef, Australia, I. Long-term growth responses of Acropora formosa (Dana 1846). J. exp. mar. Biol. Ecol. 73 : 11-35

Ott, B., Lewis, J. B. (1972). The importance of the gastropod Coralliophila abbreviata (Lamarck) and the polychaete Hermodyce carunculata (Pallas) as coral reef predators. Can. J. Zool. 50: 1651-1656

Pearson, R. G. (1981). Recovery and recolonization of coral reefs (review) Mar. Ecol. Prog. Ser. 4: 105-122

Rogers, C. S., Suchanek, T. H., Pecora, F. A. (1982). Effects of hurricanes David and Frederic (1979) on shallow Acropora palmata reef communities: St. Croix, U. S. Virgin Islands. Bull. mar. Sci. 32: 532-548

Rogers, C. S., Fitz III, H. C., Gilnack, M., Beets, J., Hardin, J. (1984). Scleractinian coral recruitment patterns at Salt River submarine canyon, St. Croix, U. S. Virgin Islands. Coral Reefs 3: 69-76 
Rylaarsdam, K. W. (1983). Life histories and abundance patterns of colonial corals on Jamaican reefs. Mar. Ecol. Prog. Ser. 13: 249-260

Sammarco, P. W. (1980). Diadema and its relationship to coral spat mortality: grazing, competition and biological disturbance. J. exp. mar. Biol. Ecol. 45: 245-272

Shinn, E. A. (1981). Time capsules in the sea. Sea Front. 27 : $364-374$

Siegel, S. (1956). Nonparametric statistics for the behavioral sciences. McGraw Hill, Kogakusha, Tokyo

Sokal, R. R., Rohlf, F. J. (1981). Biometry, 2nd ed. W. H. Freeman and co., San Francisco

Stephenson, T. A., Stephenson, A. (1933). Growth and asexual reproduction in corals. Scient. Rep. Gt Barrier Reef Exped. 3: $167-217$

Van den Hoek, C., Breeman, A. M., Bak, R. P. M., Van Buurt, G. (1978). The distribution of algae, corals and gorgonians in relation to depth, light attenuation, water movement and grazing pressure in the fringing coral reef of Curaçao, Netherlands Antilles. Aquat. Bot. 5: 1-46

Van Moorsel, G. W. N. M. (1983). Reproductive strategies in two closely related stony corals (Agaricia, Scleractinia). Mar. Ecol. Prog. Ser. 13: 273-283

Wanders, J. B. W. (1977). The role of benthic algae in the shallow reef of Curaçao (Netherlands Antilles) III: the significance of grazing. Aquat. Bot. 3: 357-390

Wulff, J. L. (1984). Sponge-mediated coral reef growth and rejuvenation. Coral Reefs 3: 157-163

Yamaguchi, M. (1983). Growth data analysis in the reef building coral Pocillopora damicomis (Linnaeus). Galaxea 2: $21-27$

This paper was submitted to the editor ${ }_{i}$ it was accepted for printing on April 20, 1985 